\title{
Dietary sodium butyrate supplementation increases digestibility and pancreatic secretion in young milk-fed calves
}

\author{
P. Guilloteau, ${ }^{* 1}$ G. Savary, ${ }^{\star}$ Y. Jaguelin-Peyrault, $†$ V. Romé, ${ }^{*}$ L. Le Normand, ${ }^{\star}$ and R. Zabielskił \\ *INRA, UMR 1079, Système d'Elevage, Nutrition Animale et Humaine (SENAH), Domaine de la Prise, 35590 Saint Gilles, France \\ †INRA, UMR 1080, PL, Domaine de la Prise, 35590 Saint Gilles, France \\ ‡Department of Physiological Sciences, Faculty of Veterinary Medicine, Warsaw University of Life Sciences, 02-766 Warsaw, Poland
}

\begin{abstract}
The aim of this study was to test, in 8 calves fed milk formula based on soybean protein, the ability of sodium butyrate (SB) supplementation to improve nutrient digestibility and daily pancreatic secretions and to modify the kinetics of these secretions. Additionally, effects of duodenal SB infusion were evaluated. Plasma levels of gastrin, secretin, and cholecystokinin were measured. Butyrate supplementation in milk formula increased nutrient digestibility and total daily pancreatic secretions. For juice volume, this increase was most important from 12 to $17 \mathrm{~h}$ after the morning meal. During the 3-h postprandial period, oral SB supplementation reduced the physiological decrease of postprandial pancreatic secretion (while duodenal digesta flow rate was maximal) and had a minor effect on plasma gut regulatory peptide concentrations. Compared with the diet without SB, ingestion of SB stimulated pancreatic secretion. Taken together, these results could explain the measured increase in nutrient digestibility. The data obtained after duodenal SB infusion did not indicate an effect on pancreatic secretion, apart from elevated lipase output compared with control. The mechanisms responsible for these events are not known and circulating gut regulatory peptides do not seem to be implicated. Our work brings new results regarding SB as a feed additive in young calf nutrition.
\end{abstract}

Key words: butyrate supplementation, digestibility, pancreatic secretion, calf

\section{INTRODUCTION}

Butyric acid, one of the volatile fatty acids, is a natural substance present in the forestomachs of ruminants and colons of monogastric species. It is also present in milk of most mammals $(0.16 \mathrm{~g} / \mathrm{L}$ in cow milk) with the exception of sow milk and only traces in human

Received September 21, 2009.

Accepted August 21, 2010.

${ }^{1}$ Corresponding author: Paul.Guilloteau@rennes.inra.fr milk (Alais, 1984). Butyrate seems to have widespread effects on growth and feed efficiency through modulation of proliferation, differentiation, and function of the gastrointestinal tract (GIT) tissues in healthy and sick animals (Pouillart, 1998; Mroz, 2005; Guilloteau et al., 2009). In animal studies and in practice, butyrate salts [i.e., sodium butyrate (SB) or calcium butyrate] are often used instead of butyric acid itself, because they are solid, stable, and much less odorous.

Nutrient digestibility can be determined simultaneously with growth and feed efficiency measurements to better appreciate the effects of a diet, but digestibility studies with SB supplementation are scarce and, to our knowledge, missing for calves (Guilloteau et al., 2004). In swine, digestibility results obtained at different levels of the GIT (ileal vs. fecal) or at different ages (before vs. after weaning) are often contradictory (Galfi and Boroki, 1990; Manzanilla et al., 2006; Le Gall et al., 2009). Few experiments have been performed to study SB effects on pancreatic secretion. In in vitro studies with goat and sheep pancreatic lobuli preparations, administration of SB resulted in enhanced amylase release (Harada and Kato, 1983; Harada, 1985). Intravenous injection (in anesthetized pigs, sheep and calves, and in conscious guinea pigs), and intraduodenal (in rats) or intra-ileal (in pigs) infusions of SB stimulated pancreatic secretion (Demol and Sarles, 1978; Sileikiene et al., 2005). Oral SB supplementation was accompanied by a $50 \%$ increase in elastase-II activity in calf pancreatic tissue (Guilloteau et al., 2009). Similarly, in pigs, this supplementation resulted in an increase of disaccharidase activities at different sites of the small intestine (Galfi et al., 1993). No experiments have been performed to date to study the effects of oral SB supplementation on pancreatic juice secretion under physiological conditions.

Supplementation of weaned pig diets with SB resulted in butyrate detection in the stomach but not in the proximal jejunum (Manzanilla et al., 2006), suggesting that SB was readily absorbed from the stomach. Recently, it has been demonstrated in calves that butyrate or $\beta$-hydroxybutyrate is not detected in plasma follow- 
ing oral administration (Guilloteau et al., 2009), which confirms rapid gastric metabolism. Several questions arise concerning the availability of orally administered $\mathrm{SB}$ to the upper gut mucosa and direct effects of SB on small intestinal function. To answer these questions, infusion studies bypassing the stomach (Demol and Sarles, 1978; Sileikiene et al., 2005) were performed.

The aim of the present study was to evaluate the effects of oral and intraduodenal SB administration in conscious calves on nutrient digestibility, total pancreatic secretion and on circadian kinetics of pancreatic secretion. Because SB is utilized in the stomach (Manzanilla et al., 2006; Guilloteau et al., 2009), we used duodenal cannula to infuse SB directly into the duodenal lumen to test its ability to improve digestive capacity.

\section{MATERIALS AND METHODS}

\section{Animals, Diets, and Feeding}

Treatments and experiments were conducted according to European Union regulations concerning the protection of experimental animals. Eight HolsteinFriesian male calves were obtained just after birth and the experiment was carried out between $54 \pm 5$ and $88 \pm 5 \mathrm{~d}$ of age. All calves were given colostrum (25 $\mathrm{g} / \mathrm{kg}$ of BW per meal) during the first $2 \mathrm{~d}$ of life and then received a milk replacer diet based on skim milk powder, whey powder, and tallow. These liquid diets were offered twice a day and were the exclusive diets until $54 \mathrm{~d}$ of age (start of the experiment). Composition (per $\mathrm{kg}$ of DM) of this milk replacer was $231 \mathrm{~g}$ of $\mathrm{CP}$ $(\mathrm{N} \times 6.25), 215 \mathrm{~g}$ of crude fat, and $76 \mathrm{~g}$ of ash. During the whole experiment (from d 54 to 88), calves were fed a milk replacer diet in which proteins were provided by an alcohol-extracted soybean concentrate (73.6\%) and whey powder. Soybean protein was chosen in this experiment because it is mostly used to replace part of the natural milk proteins in modern milk replacers for rearing calves. Its digestibility is lower than that of skim milk powder protein (Guilloteau et al., 1986a). Thus, using soybean protein it was possible to test if SB supplementation can improve nutrient digestibility.

The diet (per $\mathrm{kg}$ of DM) contained $211 \mathrm{~g}$ of $\mathrm{CP}, 211$ $\mathrm{g}$ of crude fat, $494 \mathrm{~g}$ of $\mathrm{N}$-free extract, and $84 \mathrm{~g}$ of ash. This diet was considered the control diet (C diet). Antigenic activity against certain soy proteins was very low as were other antinutritional factors such as lectins, which were not detected. Composition details of the milk replacer given before experimentation (based on milk proteins) and that offered during the experimentation (based on soybean proteins) were reported by Le Dréan et al. (1998). Switching between diets was pro- gressively accomplished over $3 \mathrm{~d}$ during the week before the experiment. In the $\mathrm{C}$ diet, an antibiotic (bacitracin) used as a growth factor was incorporated $(8 \mathrm{mg} / \mathrm{kg}$ of $\mathrm{DM}$ ). The effect of SB supplementation was tested by adding $3 \mathrm{~g}$ of $\mathrm{SB} / \mathrm{kg}$ of $\mathrm{DM}$ to the $\mathrm{C}$ diet to formulate the butyrate (B) diet. Calves were fed from buckets twice daily at 0830 and $1630 \mathrm{~h}$. The DM intake was 66 $\mathrm{g} / \mathrm{kg}$ of $\mathrm{BW}^{0.75}$ per day.

\section{Experimental Design and Calf Management}

In the first study, dietary effects of SB supplementation were tested in 4 calves. The experiment was divided into 4 periods (P0 to P3). During the preexperimental period ( $\mathrm{P} 0)$, calves were fed the $\mathrm{C}$ diet before surgical intervention. Two permanent cannulas were inserted into the pancreatic duct and duodenum under halothane anesthesia in each calf at 2 mo of age as described previously (Le Dréan et al., 1997). During P1, the same diet was fed as during P0. During P2, calves were progressively switched, over $3 \mathrm{~d}$, from diet $\mathrm{C}$ to $\mathrm{B}$ and then adapted over $5 \mathrm{~d}$ to this diet. During P3, calves were fed entirely with diet B.

Total feces were collected over 4 consecutive days of each period, and representative aliquots were frozen before subsequent freeze-drying and analysis. Apparent digestibility was measured in P0 (after $45 \mathrm{~d}$ of age) and in P1, P2, and P3 (Table 1). On the third day of P1, $\mathrm{P} 2$, and P3, pancreatic juice was totally and continuously collected (for $24 \mathrm{~h}$ ), measured, and reintroduced $(92 \%)$ into the duodenum by means of a pump that extracted a constant proportion (8\%) of pancreatic juice at 5-min intervals (Le Dréan et al., 1998). The secretion of pancreatic juice was recorded by using a computer (volume as a function of real time). Pancreatic juice was only sampled from 0.5 to $3.0 \mathrm{~h}$ after the morning meal, for a total of 42 samples. These samples were immediately transferred into a fraction collector at $4^{\circ} \mathrm{C}$, and aliquots were stored at $-20^{\circ} \mathrm{C}$ until analyzed. Similarly, a supplementary aliquot was prepared from pancreatic juice collected during the remainder of the day. When sampling was not being conducted, both cannulas (pancreatic and duodenal) were connected to allow free flow of pancreatic juice into the duodenum. At the end of the d 4 of each experimental period, calves were fitted with a jugular vein catheter to collect blood samples. On d 5 of each period, blood samples were collected into tubes containing heparin (500 UI/ $\mathrm{mL}$ ) and aprotinin $(10,000 \mathrm{UI} / \mathrm{mL})$ at 60 and $30 \mathrm{~min}$ before the morning meal and 5, 15, 30, 45, 60, 90, 120, 150, 180, and 210 min after the meal. Plasma samples were stored at $-20^{\circ} \mathrm{C}$ until analysis.

In study 2, effects of duodenal SB infusion were evaluated in 4 calves used in the previous experiment (study 
Table 1. Effect of Na-butyrate supplementation on BW, growth rate, and DM digestibility during each period of measurement

\begin{tabular}{|c|c|c|c|c|c|}
\hline \multirow[b]{2}{*}{ Item } & \multicolumn{4}{|c|}{ Experimental period and $\operatorname{diet}^{1}$} & \multirow[b]{2}{*}{ SEM } \\
\hline & $\begin{array}{c}\mathrm{P} 0 \\
\operatorname{diet} \mathrm{C}\end{array}$ & $\begin{array}{c}\mathrm{P} 1 ; \\
\operatorname{diet} \mathrm{C}\end{array}$ & $\begin{array}{c}\mathrm{P} 2 ; \\
\operatorname{diet} \mathrm{B}\end{array}$ & $\begin{array}{c}\text { P3; } \\
\operatorname{diet~B~}\end{array}$ & \\
\hline Calves (n) & 4 & 4 & 4 & 4 & \\
\hline $\mathrm{BW}(\mathrm{kg})$ & $67.7^{\mathrm{a}}$ & $88.5^{\mathrm{b}}$ & $93.7^{\mathrm{c}}$ & $96.8^{\mathrm{c}}$ & 3.0 \\
\hline Relative growth rate $(\mathrm{g} / \mathrm{d}$ per $100 \mathrm{~kg}$ of $\mathrm{BW})$ & 420 & 504 & 396 & 479 & 46.9 \\
\hline DM digestibility $(\%)$ & $92.7^{\mathrm{ac}}$ & $91.5^{\mathrm{bc}}$ & $93.3^{\mathrm{a}}$ & $93.7^{\mathrm{a}}$ & 0.4 \\
\hline
\end{tabular}

${ }^{\mathrm{a}-\mathrm{c}}$ Means within a row with different superscripts differ $(P<0.05)$.

${ }^{1}$ During P0 and P1 calves were fed the $\mathrm{C}$ diet; during P2 and P3 calves were fed the B diet; calves were fitted with duodenal and pancreatic catheters between P0 and P1. $\mathrm{C}=$ control diet: milk formula in which proteins were provided by a soybean concentrate $(73.6 \%)$ and whey powder; $\mathrm{B}=$ butyrate diet: $\mathrm{C}$ diet supplemented with $3 \mathrm{~g}$ of Na-butyrate/kg of DM.

1) during d 6 of P1, P2, and P3. A control solution of $\mathrm{NaCl}$ 0.9\% (saline infusion, during P1) or SB solution (SB infusion, during P2 and P3) was infused from 5 to $7 \mathrm{~h}$ after the morning meal when proximal digestion of the meal was largely completed (Guilloteau et al., 1979). The quantity of SB infused was identical to that incorporated in each meal for the calves used in study 1. This quantity was diluted in $10 \mathrm{~mL}$ of $0.9 \% \mathrm{NaCl}$ solution and infused over $1 \mathrm{~min}$ with a peristaltic pump commencing $5.5 \mathrm{~h}$ after the morning meal. As a control, $10 \mathrm{~mL}$ of $0.9 \% \mathrm{NaCl}$ solution was infused under the same conditions. Pancreatic juice was collected at 5 -min intervals over $2 \mathrm{~h}$, and blood samples were obtained at 30 and 20 min before and 5, 15, 25, 35, 45, 60, and 90 min after beginning infusions as described above. For each collection of pancreatic juice, the 30-min period preceding infusion was assumed to be the basal period.

For technical reasons (e.g., fraction collector stoppage, catheter removal or blockage), it was difficult to complete 4 successive entire periods from the same cannulated calf. Four additional calves were cannulated and used as required. These calves could not be included in the digestibility studies but were partly included in pancreatic measurements and plasma sample collections in both studies. Measurements at the beginning of pancreatic secretions and their duration (from 0.5 before to $3.5 \mathrm{~h}$ after the morning meal for study 1 , and from 5 to $7 \mathrm{~h}$ after the morning meal for study 2) were chosen in agreement with our earlier data obtained in calves (Le Dréan et al., 1998). These 2 periods are reported as indicated in Figure 1. The first interval was considered the postprandial period and the second the basal period.

\section{Laboratory Methods}

Diets and feces were analyzed for DM, nitrogen, fat, ash, calcium, and phosphorus, according to described previously methods (Branco-Pardal et al., 1995). Total protein concentration in pancreatic juice was determined (Lowry et al., 1951) as were enzyme activities for chymotrypsin (EC 3.4.21.2) and lipase (EC 3.1.1.3), as described by Guilloteau et al. (2009). Enzyme activities were expressed in International Units (IU). Plasma concentrations of gastrin and secretin were measured by RIA as described previously except that in the present study carbon dextran was used to extract non-antibody bound hormone instead of a secondary antibody (Guilloteau et al., 2009). Cholecystokinin (CCK) was determined using a commercially available kit (EURIA_CCK, Eurodiagnostica, Malmö, Sweden). Results are expressed in picomoles of equivalents of standard per liter of plasma.

\section{Statistical Analysis}

The General Linear Model procedure of SAS, using ANOVA for repeated measures, was used for statistical evaluation (release 6.12 for Windows; SAS Institute Inc., Cary, NC). Digestibility and daily pancreatic secretion means were classified according to the Friedman test. Area under the concentration curve (AUC) was calculated to evaluate response of pancreatic secretion and gut regulatory peptides using GraphPad Prism v.5.02 (GraphPad Software, San Diego, CA). Preliminary data analysis revealed that pancreatic response was resumed within $1.5 \mathrm{~h}$ (data not shown), and this data set was used from each experiment to calculate AUC. Effect of age was not taken into account in the statistical analysis because large changes were observed before 1 mo of age. In contrast, very little variation exists in nutrient digestibility (Grongnet et al., 1981), pancreatic secretions relative to BW (Guilloteau et al., 1995), and plasma level of gut regulatory peptides (Guilloteau et al., 1992) after 1.5 mo of age in milk-fed calves. Effects were considered significant at $P<0.05$ 
and tendencies when $P<0.10$. Data are presented as mean \pm SEM.

\section{RESULTS}

The calves used remained clinically healthy during the entire study; growth rate was normal for cannulated animals (Table 1) and not affected by diet (461 \pm 89 vs. $450 \pm 125 \mathrm{~g} / \mathrm{d}$ per $\mathrm{kg}$ of $\mathrm{BW}$, respectively, during $\mathrm{P} 0+\mathrm{P} 1$ and $\mathrm{P} 2+\mathrm{P} 3$; nonsignificant).

\section{Effect of Butyrate Ingestion on Digestibility, Pancreatic Secretion, and Plasma Gut Regulatory Peptide Concentrations}

Calves fed the $\mathrm{C}$ diet showed no differences between values obtained for apparent fecal digestibility before (P1) and after (P2) surgical operation, as shown for DM in Table 1 and for all nutrients studied (data not shown). Similarly, no differences were found between P2 and P3 when calves were fed the B diet (data not shown). Therefore, data from P0 and P1 (during which calves were fed the $\mathrm{C}$ diet) and P2 and P3 (during which calves were fed the $\mathrm{B}$ diet) were combined (Table 2 ). For calves on the $\mathrm{B}$ diet, DM and $\mathrm{N}$ digestibilities tended to be higher, whereas OM, N-free extract, and phosphorus digestibilities were not modified compared with the $\mathrm{C}$ diet. Digestibility of fat, ash, and calcium increased with SB supplementation by 4.4, 6.9, and $12.0 \%$, respectively $(P<0.05$; Table 2$)$.
Table 2. Effect of Na-butyrate supplementation on nutrient digestibility

\begin{tabular}{lccc}
\hline & \multicolumn{2}{c}{ Experimental period and diet ${ }^{1}$} & \\
\cline { 2 - 3 } & $\begin{array}{c}\text { P0+P1; } \\
\text { diet C }\end{array}$ & $\begin{array}{c}\text { P2+P3; } \\
\text { diet B }\end{array}$ & SEM \\
\hline Calves (n) & 4 & 4 & - \\
Periods (n) & 8 & 8 & - \\
Digestibility (\%) & & & \\
DM & $92.1^{\mathrm{a}}$ & $93.6^{\mathrm{b}}$ & 0.4 \\
OM & 92.4 & 93.3 & 0.5 \\
Nitrogen & $85.7^{\mathrm{a}}$ & $86.8^{\mathrm{b}}$ & 0.8 \\
Fat & $88.8^{\mathrm{c}}$ & $92.7^{\mathrm{d}}$ & 0.9 \\
N-free extract & 96.4 & $98.1^{\mathrm{c}}$ & 0.5 \\
Ash & $76.6^{\mathrm{c}}$ & $81.9^{\mathrm{d}}$ & 1.2 \\
Calcium & $59.0^{\mathrm{c}}$ & $66.1^{\mathrm{d}}$ & 2.2 \\
Phosphorus & 77.7 & 79.4 & 2.0 \\
\hline
\end{tabular}

${ }^{\mathrm{a}-\mathrm{d}}$ Means within a row with different superscripts $\operatorname{differ}\left({ }^{\mathrm{a}, \mathrm{b}} P<0.10\right.$ and $\left.{ }^{\mathrm{c}, \mathrm{d}} P<0.05\right)$.

${ }^{1}$ During $\mathrm{P} 0$ and $\mathrm{P} 1$ calves were fed the $\mathrm{C}$ diet; during $\mathrm{P} 2$ and $\mathrm{P} 3$ calves were fed the $\mathrm{B}$ diet; calves were fitted with duodenal and pancreatic catheters between $\mathrm{P} 0$ and $\mathrm{P} 1 . \mathrm{C}=$ control diet: milk formula in which proteins were provided by a soybean concentrate $(73.6 \%)$ and whey powder; $\mathrm{B}=$ butyrate diet: $\mathrm{C}$ diet supplemented with $3 \mathrm{~g}$ of Na-butyrate $/ \mathrm{kg}$ of DM. For this analysis data from P0 and P1 were combined, as were those of P2 and P3.

Compared with that on the $\mathrm{C}$ diet, total daily pancreatic juice secretion relative to BW tended to increase $(P<0.10)$ and total protein secretion was 1.4 fold higher $(P<0.05)$ with the $\mathrm{B}$ diet, even if protein concentration in juice was not modified (Table 3). For the 2 enzymes studied, neither activities per milliliter of juice nor specific activities were modified by SB supple-

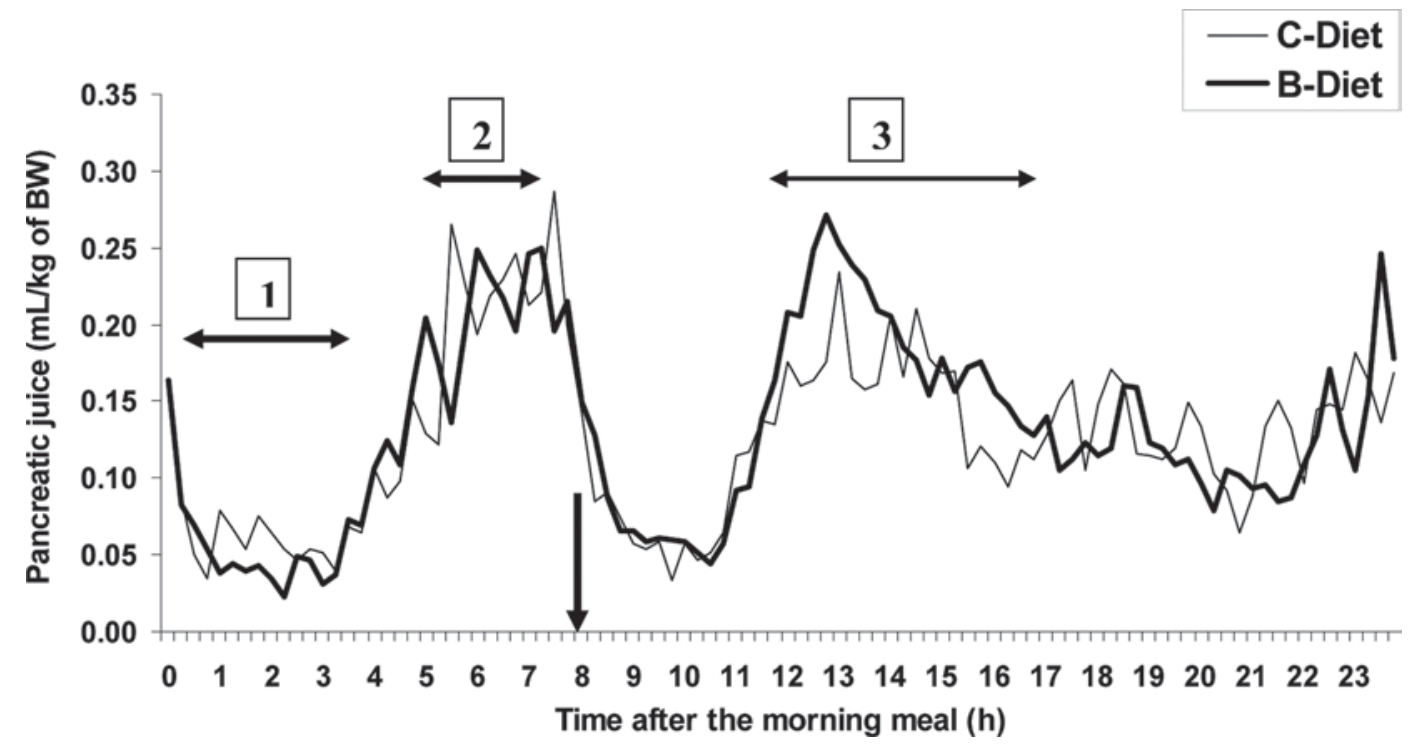

Figure 1. Effects of butyrate ingestion on kinetics of pancreatic juice output during a 24-h period. $\mathrm{n}=7$ (control diet, C) and 11 (butyrate diet, B). Time of day: $0=0830 \mathrm{~h}$ (morning meal); $8=1630 \mathrm{~h}$ (evening meal). $\leftarrow 1 \rightarrow$ indicates duration of butyrate ingestion experiment and $\leftarrow 2 \rightarrow$ indicates duration of duodenal butyrate perfusion experiment throughout the day in relation to periods of pancreatic secretion. During $\leftarrow 3 \rightarrow$, values obtained for the $\mathrm{B}$ diet were higher than those obtained with the $\mathrm{C}$ diet (area under the curve; $P<0.05$ ). 
Table 3. Effect of Na-butyrate supplementation on pancreatic secretions

\begin{tabular}{|c|c|c|c|}
\hline \multirow[b]{2}{*}{ Item } & \multicolumn{2}{|c|}{ Experimental period and $\operatorname{diet}^{1}$} & \multirow[b]{2}{*}{ SEM } \\
\hline & $\begin{array}{l}\mathrm{P} 1 ; \\
\operatorname{diet} \mathrm{C}\end{array}$ & $\begin{array}{c}\mathrm{P} 2+\mathrm{P} 3 \\
\operatorname{diet} \mathrm{B}\end{array}$ & \\
\hline Calves (n) & 4 & 4 & - \\
\hline Periods (n) & 4 & 8 & - \\
\hline Pancreatic juice (g/d per $\mathrm{kg}$ of $\mathrm{BW}$ ) & $8.6^{\mathrm{a}}$ & $10.8^{\mathrm{b}}$ & 0.8 \\
\hline \multicolumn{4}{|c|}{ Pancreatic juice concentration (/mL of juice) } \\
\hline Total protein $(\mathrm{mg})$ & 9.7 & 10.0 & 1.3 \\
\hline Chymotrypsin (IU) & 41.7 & 46.6 & 9.2 \\
\hline Lipase (IU) & 204.6 & 211.1 & 40.5 \\
\hline \multicolumn{4}{|c|}{ Enzymatic specific activity (IU/mg of proteins) } \\
\hline Chymotrypsin & 4.2 & 4.5 & 0.4 \\
\hline Lipase & 20.7 & 20.7 & 2.0 \\
\hline \multicolumn{4}{|l|}{ Daily production (/d per $\mathrm{kg}$ of $\mathrm{BW})$} \\
\hline Total protein $(\mathrm{mg})$ & $76.6^{\mathrm{c}}$ & $105.7^{\mathrm{d}}$ & 12.4 \\
\hline Chymotrypsin activity (IU) & $281.1^{\mathrm{a}}$ & $427.6^{\mathrm{b}}$ & 77.7 \\
\hline Lipase activity (IU) & $1,570^{\mathrm{c}}$ & $2,210^{\mathrm{d}}$ & 325 \\
\hline
\end{tabular}

${ }^{\mathrm{a}-\mathrm{d}}$ Means within a row with different superscripts $\operatorname{differ}\left({ }^{\mathrm{a}, \mathrm{b}} P<0.10\right.$ and $\left.{ }^{\mathrm{c}, \mathrm{d}} P<0.05\right)$.

${ }^{1}$ During $\mathrm{P} 1$ calves were fed the $\mathrm{C}$ diet; during P2 and P3 calves were fed the B diet; calves were fitted with duodenal and pancreatic catheters before $\mathrm{P} 1 . \mathrm{C}=$ control diet: milk formula in which proteins were provided by a soybean concentrate $(73.6 \%)$ and whey powder; $\mathrm{B}=$ butyrate diet: $\mathrm{C}$ diet supplemented with $3 \mathrm{~g}$ of Nabutyrate/kg of DM. Data from P2 and P3 are combined.

mentation. In contrast, daily total production relative to BW were increased by $52 \%$ for chymotrypsin $(P<$ $0.10)$ and by $40 \%$ for lipase $(P<0.05)$.

Kinetics of pancreatic juice flow rate $(\mathrm{mL} / 5 \mathrm{~min})$ measured during the whole day are reported in Figure 1. With the $\mathrm{C}$ diet, pancreatic juice secretion decreased after the morning meal, reaching a plateau for $3 \mathrm{~h}$, and then increased from 4 to $5 \mathrm{~h}$. At the end of this period, the evening meal effect was similar to that of the morning meal. The profile of juice secretion on the $\mathrm{B}$ diet was not different from control, except for secretion from 12 to $17 \mathrm{~h}$ after the morning meal, when it was higher compared with the $\mathrm{C}$ diet response (AUC; $P<0.05)$.

Expressed per kilogram of BW and compared with that on the $\mathrm{C}$ diet, basal pancreatic juice and enzyme secretions were not changed with the $\mathrm{B}$ diet but decreased for protein flow rate $(1.92 \pm 1.15$ vs. $0.54 \pm$ $0.42 \mathrm{mg} / \mathrm{h}$ per $\mathrm{kg}$ of BW, respectively, $P<0.05$; Figure 2 ). During the 3 -h postprandial period, SB supplementation did not modify the mean flow rate for juice, proteins, or chymotrypsin but increased that of lipase $(13.6 \pm 3.2$ vs. $20.4 \pm 2.0 \mathrm{IU} / \mathrm{h}$ per $\mathrm{kg}$ of $\mathrm{BW}$, respectively, for the $\mathrm{C}$ and $\mathrm{B}$ diets; AUC, $P<0.01$; Figure $2)$. Similarly, lipase activity in juice was higher with the B diet from 1 to $3 \mathrm{~h}$ postprandially $(221 \pm 9$ vs. 129 $\pm 17 \mathrm{IU} / \mathrm{mL} ; P<0.05$ ), whereas protein concentration and chymotrypsin activity were not modified (data not shown). On the $\mathrm{C}$ diet and compared with basal values, pancreatic flow rate strongly decreased during the first postprandial $30 \mathrm{~min}(-63,-61,-61$, and $-70 \%$, respectively, for juice, proteins, chymotrypsin, and lipase; $P<0.05$ ). On the $\mathrm{B}$ diet, this decrease was smaller than that observed on the $\mathrm{C}$ diet for all parameters measured [corresponding values were $-57 \%$ $(P<0.05),-25 \%(P>0.1),-48 \%(P<0.05)$, and $-39 \%(P>0.1)$; Figure 2]. Thus, just after the meal, SB supplementation reduced the decrease of pancreatic juice flow rate and its protein components. During the first postprandial hour and compared with the $\mathrm{C}$ diet, ingestion of the B diet did not modify juice and protein flow rate but did increase enzyme activities $(+34$ and $+30 \%$ for chymotrypsin and lipase, respectively, AUC; $P<0.05)$.

For each gut regulatory peptide studied, basal values were similar with both diets (Figure 2). Postprandial kinetics of plasma concentrations were not modified by $\mathrm{SB}$ ingestion. Compared with those on the $\mathrm{C}$ diet, mean concentrations during the 3.5 -h postprandial period tended to increase with the B diet for secretin $(+43 \%$; $P<0.1)$ but not for gastrin $(+10 \%$; NS). That of CCK tended to increase only during the third postprandial hour (+90\%; $P<0.1$; Figure 2 and data not shown).

\section{Effect of Duodenal SB Infusion on Pancreatic Secretion and Plasma Gut Regulatory Peptide Concentrations}

Effects of duodenal SB infusion are shown in Figure 3. Expressed per kilogram of BW and compared with saline infusion, basal secretion was not changed with SB infusion for juice, protein, or chymotrypsin flow rate but was higher for lipase flow rate $(P<0.05$; Figure 3 and data not shown). Compared with basal 

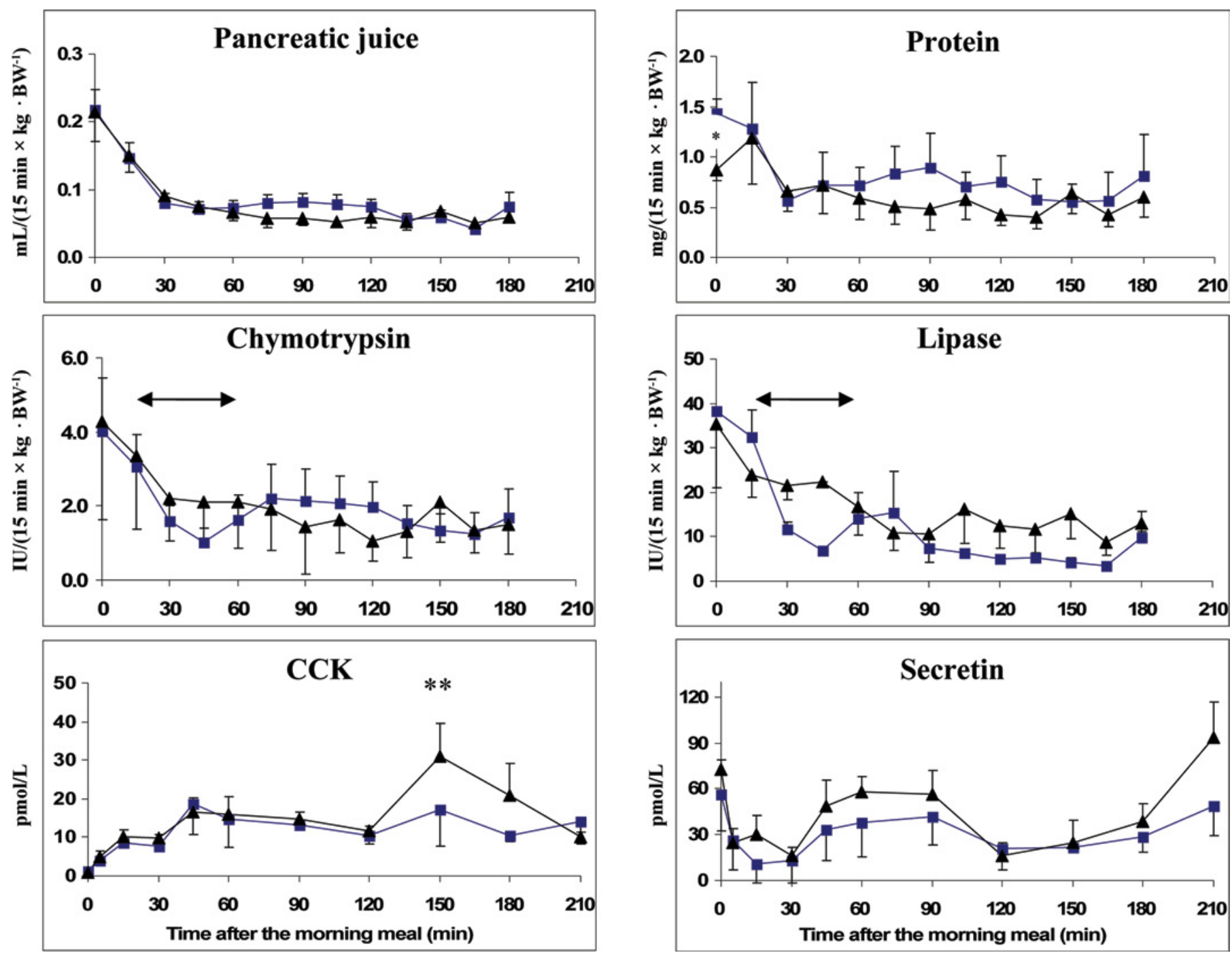

Figure 2. Effects of butyrate feeding on pancreatic secretion $[\mathrm{n}=4$ for control $\operatorname{diet}(\mathrm{C}, \boldsymbol{\square})$ and $\mathrm{n}=8$ for butyrate diet (B, $\mathbf{\Delta})]$ and on plasma gut regulatory peptide concentrations $\left(\mathrm{n}=8\right.$ for each diet); $\mathrm{CCK}=$ cholecystokinin. Data are means $\pm \mathrm{SEM}$. ${ }^{*}, * *$ Values obtained with $\mathrm{B}$ diet were different $(P<0.05)$ or tended to be different $(P<0.10)$ from those obtained with the $\mathrm{C}$ diet. $\leftrightarrow$ : Enzyme secretions were increased during the first postprandial hour $(P<0.05)$ for the $\mathrm{B}$ diet compared with the $\mathrm{C}$ diet. Color version available in the online PDF.

values, no changes in pancreatic flow rate (juice and components) were observed during $1.5 \mathrm{~h}$ postinfusion for all measured parameters. During this 1.5 -h period, SB infusion did not affect pancreatic mean flow rate for juice and proteins, but chymotrypsin secretion rate was lower $(6.8 \pm 0.5$ vs. $3.9 \pm 0.3 \mathrm{IU} / \mathrm{h}$ per $\mathrm{kg}$ of $\mathrm{BW}$ for saline infusion and SB infusion, respectively; $P<0.05$ ), whereas lipase secretion rate (during the first $30 \mathrm{~min}$ ) was higher (AUC; $P<0.05$ ). Globally, protein, chymotrypsin, and lipase concentrations in juice were not modified by duodenal SB infusion (data not shown).

For each gut regulatory peptide studied, basal values were similar with both treatments (Figure 3). Mean concentrations during the 1.5 -h period post-infusion were not modified by SB infusion for gastrin and se- cretin. Only that of CCK tended to increase (AUC; $P$ $<0.10)$. Moreover, the profiles of post-infusion kinetics of plasma peptide concentrations were modified by SB infusion, resulting in significant differences $(P<0.05)$ between treatments for gastrin and secretin concentrations, but only for brief periods after infusion (from 5 to 15 min for gastrin and from 15 to 30 min for secretin; Figure 3 and data not shown).

\section{DISCUSSION}

In the present work, we used young calves to study the effects of sodium butyrate added at a low dose $(0.3 \%$ of DM) in milk formula usually offered in rearing conditions. Effects on nutrient digestibility and pancreatic 

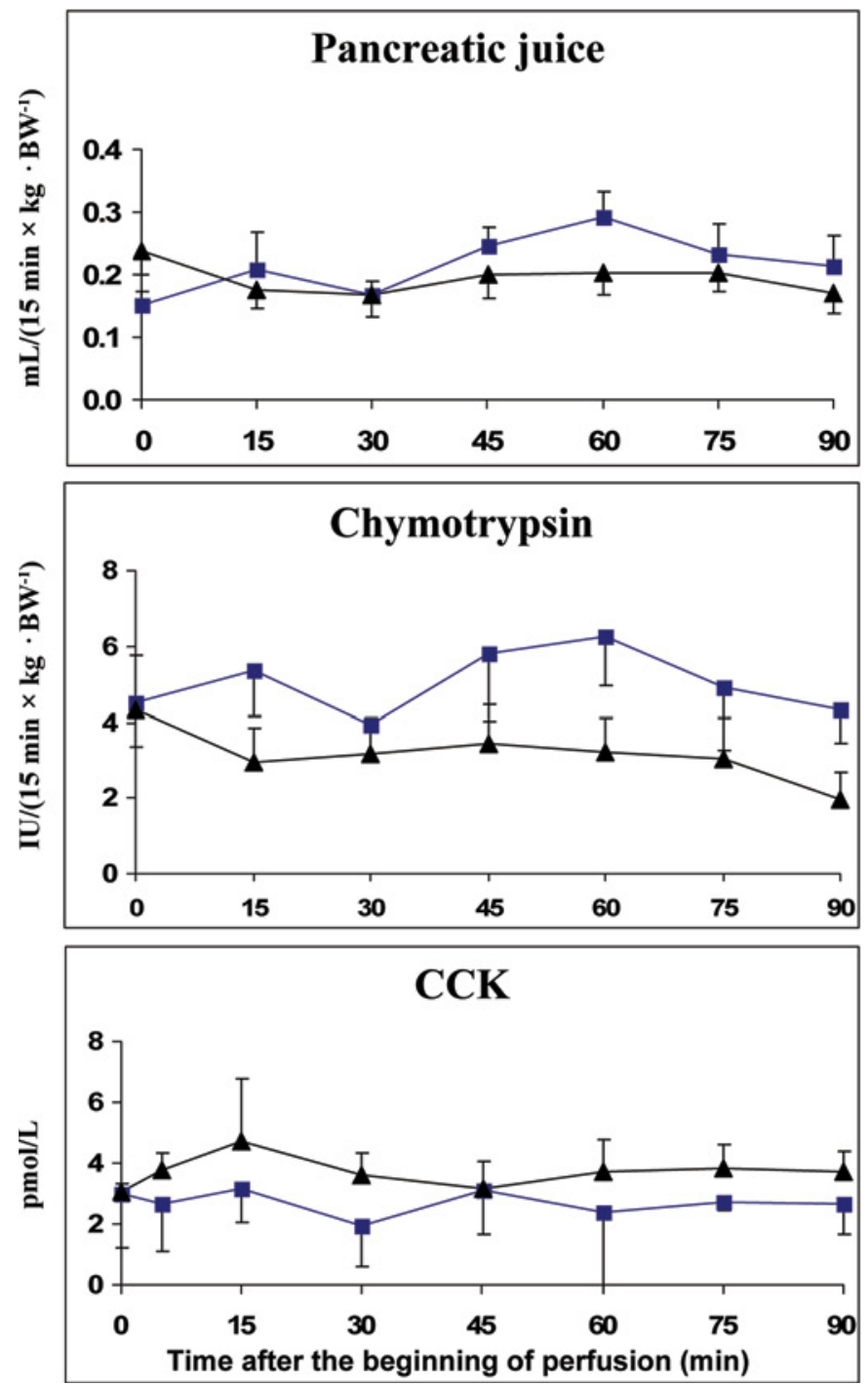
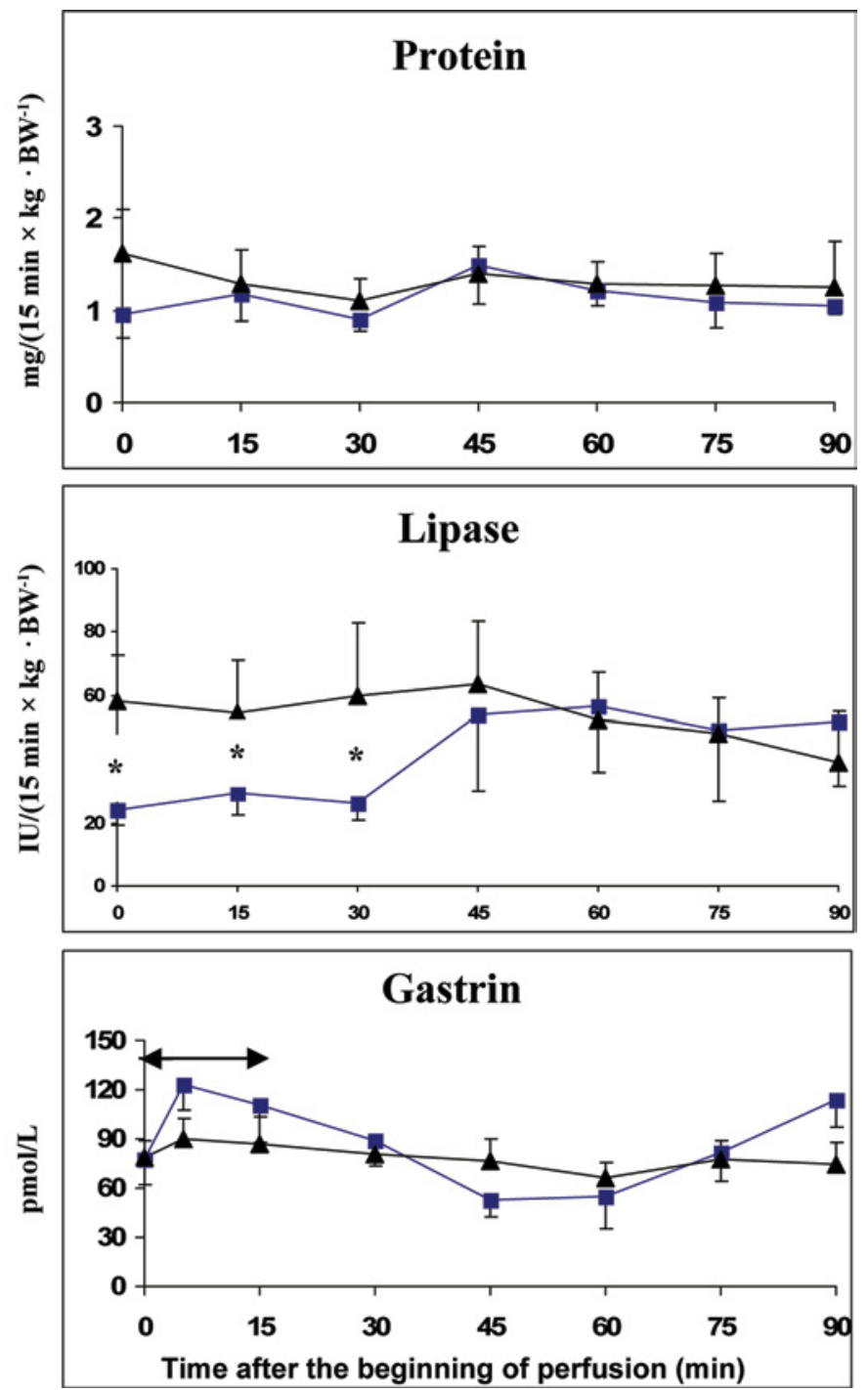

Figure 3. Effects of butyrate duodenal perfusion on pancreatic secretion $[n=7$ for saline infusion ( $\square)$ and 8 for butyrate infusion $(\boldsymbol{\Lambda})]$ and on plasma gut regulatory peptide concentrations $\left(\mathrm{n}=8\right.$ for each substance infusion); CCK $=$ cholecystokinin. Data are mean \pm SEM. ${ }^{*}$ Values obtained with butyrate infusion were different $(P<0.05)$ from those obtained with saline infusion. $\leftrightarrow$ : Plasma gastrin concentration was lower during the first post-perfusion $15 \min (P<0.05)$ when butyrate infusion was compared with saline infusion. Color version available in the online PDF.

secretion (juice and some of its protein components) were measured in animals surgically fitted with pancreatic duct catheters; plasma gut regulatory peptide (gastrin, CCK, secretin) concentrations were measured simultaneously. To our knowledge, this is the first demonstration of pancreatic secretion kinetics in response to oral administration of sodium butyrate in conscious animals under physiological conditions. The main conclusion from our study is that SB supplementation can increase total daily pancreatic secretion (in particular chymotrypsin and lipase) and tends to increase the digestibility of proteins. Moreover, SB supplementation modified circadian kinetics of pancreatic juice secretion by reducing the decrease of pancreatic secretion usually observed after meal ingestion, whereas duodenal flow rate was maximal at the same time (Guilloteau et al., 1979). Sodium butyrate supplementation had little effect on plasma concentrations of secretin and CCK. Finally, duodenal SB infusion seemed to have little effect on pancreatic secretion but had some effects opposite to those observed after SB ingestion.

Data on digestibility of the $\mathrm{C}$ diet corroborate previously observed results in young calves (Guilloteau et al., 1986a; Toullec and Lallès, 1995). Le Gall et al. (2009) have shown that SB fed to pigs during the suckling period did not affect ileal digestibility but im- 
proved fecal apparent digestibility of feed components after weaning. In contrast, SB provided after weaning strongly decreased ileal digestibility of both DM and N, with less marked effects at the fecal level. Our results demonstrate that SB ingestion directly improves DM digestibility and that of its major components in calves fed milk formula based on soybean protein.

In our calves, the automatic system of pancreatic juice reintroduction allowed us to measure effects of SB supplementation on total daily secretion as well as its circadian pattern. Control data, involving total daily secretion and daily kinetics, were in agreement with previously published data in calves of similar age and fed a similar diet (Le Dréan et al., 1998). Few studies exist on the effects of SB on the exocrine pancreas. In calf pancreatic tissue, Guilloteau et al. (2009) showed that long-duration SB supplementation increased elastase II activity. Acute administration of SB stimulated pancreatic fluid and amylase secretion dose dependently in various animal models in vivo and ex vivo (Katoh and Tsuda, 1987; Ohbo et al., 1996). The results obtained in the present study on pancreatic duct-cannulated calves and previously in intact calves demonstrate that the total daily pancreatic juice, protein quantities, and chymotrypsin and lipase activities, relative to $\mathrm{BW}$, increased after SB supplementation. Moreover, in the immediate postprandial period, SB supplementation modified the kinetics of pancreatic juice secretion. The effect may be relevant for overall digestive processes, because the arrival of gastric digesta in the duodenal lumen is the highest in the 2 to $3 \mathrm{~h}$ postprandial (Guilloteau et al., 1979; Guilloteau and Zabielski, 2005). These observations help to explain, at least in part, the increase of nutrient digestibility with SB supplementation. This hypothesis is supported by the fact that lipase is the pancreatic juice component that was the most affected, as was the case for fat digestibility.

Ingestion of meals resulted in an increase of plasma gastrin and CCK concentration and a decrease of secretin, as was previously shown. These results are in agreement with the increase of pancreatic protein concentration in juice, on the one hand, and the decrease of juice secretion, on the other hand (Guilloteau et al., 1986b; Le Dréan et al., 1997, 1998). The tendency to increase plasma CCK concentration $3 \mathrm{~h}$ after ingestion of a meal could be associated with increases in protein and enzyme secretions during this period. The increase, although small, may reflect a local release of CCK in the duodenum and induction of a local neuro-hormonal mechanism that depends on CCK and vagal nerve activity (Zabielski et al., 1998b; Konturek et al., 2003). However, overall plasma concentrations of the 3 gut regulatory peptides measured in this study did not seem to explain all variation in concentrations (proteins) or activities (enzymes) and in flow rate (juice, proteins, and enzymes) of pancreatic secretions.

Butyrate given orally disappears in the upper GIT (mainly in the stomach) and is probably entirely metabolized in the GIT wall (as it was not found in blood; Manzanilla et al., 2006, Guilloteau et al., 2009). In our study, duodenal infusion was used to assess SB capability to stimulate pancreatic secretion from the small intestine in conscious calves. In conscious rats, duodenal infusion of SB tended to increase volume and protein output but this effect was not different from control secretion (Demol and Sarles, 1978). Pancreatic juice sampling pattern in their study, however, did not allow the measurement of kinetics of pancreatic secretion. In pigs, intra-ileal administration of $\mathrm{SB}$ at low dose $(5 \mathrm{mM})$ caused immediate increase of trypsin and protein outputs, which had no effect at higher dose (10 $\mathrm{n} M$ ) of butyrate (Sileikiene et al., 2005). In our work, elevated lipase activity during $1 \mathrm{~h}$ after SB infusion seems to be related to a high basal level rather than to a direct effect of SB. Infusion of SB did not change mean flow rate of juice and proteins for $1 \mathrm{~h}$ after initiating administration, in contrast to results following oral supplementation. In contrast to ingestion, SB infusion decreased mean flow rate of chymotrypsin. Little change was observed for plasma CCK concentration after SB ingestion or after SB infusion. Taken together, these results indicate that the presence of SB in the proximal intestinal lumen does not seem to affect pancreatic secretion, in contrast to the results from studies in rats and pigs cited above. It seems quite probable that oral SB stimulates pancreatic secretion through a stomachderived mechanism; for example, gastro-pancreatic long or short vago-vagal reflexes or some regulatory peptides produced by stomach mucosa. Our measurements of gut regulatory peptides did not reveal differences mostly due to high data scatter obtained by neglecting physiological oscillations in plasma CCK, secretin, and gastrin concentrations in phase with duodenal migrating motor complex (Zabielski et al., 1998a).

In conclusion, our work shows that oral butyrate supplementation at a low dose ( $0.3 \%$ of DM intake) increased digestibility of some components (fat, ash, Ca) in calves fed a milk formula based on soybean protein. These results are probably related to stimulation of total daily pancreatic secretion relative to BW, but also to modification of the circadian profile of pancreatic secretions. Thus, during the 3 -h postprandial period (and mainly during the first hour), oral SB supplementation improved pancreatic secretions when the digesta flow rate from gastric emptying was maximal, requiring higher pancreatic enzyme output. Compared with the control diet, SB administration stimulated pancreatic secretion, which may explain, at least in part, increased 
digestibility of some diet components. The mechanisms responsible are not clear, but circulating gut regulatory peptides such as CCK, gastrin, and secretin do not seem implicated, although their local neurohormonal action in gut mucosa needs to be clarified. Our study supports the rationale for the use of sodium butyrate as a feed additive in calf nutrition practice and probably in other young mammalian species including humans.

\section{ACKNOWLEDGMENTS}

This study was co-financed by the grants obtained within the frame of Polonium Program (no. 13968PE). The authors gratefully acknowledge J. H. Burton (University of Guelph, Guelph, Canada) for the English revision of the manuscript.

\section{REFERENCES}

Alais, C. 1984. Science du lait. Principes des Techniques Laitières. Société d'Edition et de Promotion Agro-alimentaire, Industrielles et Commerciales, Paris, France.

Branco-Pardal, P., J. P. Lallès, M. Formal, P. Guilloteau, and R. Toullec. 1995. Digestion of wheat gluten and potato protein by the preruminant calf: Digestibility, amino acid composition and immunoreactive proteins in ileal digesta. Reprod. Nutr. Dev. 35:639-654.

Demol, P., and H. Sarles. 1978. Action of fatty acids on the exocrine pancreatic secretion of the conscious rat: Further evidence for a protein pancreatic inhibitory factor. J. Physiol. 275:27-37.

Galfi, P., and J. Bokori. 1990. Feeding trial in pigs with a diet containing sodium n-butyrate. Acta Vet. Hung. 38:3-17.

Galfi, P., G. Gabel, and H. Martens. 1993. Influences of extracellular matrix components on the growth and differentiation of ruminal epithelial cells in primary culture. Res. Vet. Sci. 54:102-109.

Grongnet, J. F., P. Patureau-Mirand, R. Toullec, and J. Prugnaud. 1981. Utilisation of milk and whey proteins by the young preruminant calf. Influence of age and whey protein denaturation. Ann. Zootech. 30:443-464. (In French)

Guilloteau, P., T. Corring, J. A. Chayvialle, C. Bernard, J. W. Sissons, and R. Toullec. 1986b. Effect of soya protein on digestive enzymes, gut hormone and anti-soya antibody plasma levels in the preruminant calf. Reprod. Nutr. Dev. 26:717-728.

Guilloteau, P., I. Le Huërou-Luron, J. A. Chayvialle, A. Mouats, C. Bernard, J. C. Cuber, J. Burton, A. Puigserver, and R. Toullec. 1992. Plasma and tissue levels of digestive regulatory peptides during postnatal development and weaning in the calf. Reprod. Nutr. Dev. 32:285-296.

Guilloteau, P., I. Le Huërou-Luron, C. H. Malbert, and R. Toullec. 1995. Digestive secretions and their regulations. Pages 489-526 in Nutrition des Ruminants Domestiques. R. Jarrige, Y. Ruckebusch, C. Demarquilly, M. H. Farce, M. Journet, ed. INRA, Paris, France. (In French)

Guilloteau, P., V. Romé, L. Le Normand, G. Savary, and R. Zabielski 2004. Is Na-butyrate a growth factor in preruminant calf? Preliminary results. J. Anim. Feed Sci. 13(Suppl.1):393-396.

Guilloteau, P., R. Toullec, J. F. Grongnet, P. Patureau-Mirand, J Prugnaud, and D. Sauvant. 1986a. Digestion of milk, fish and soya-bean protein in the preruminant calf: flow of digesta, apparent digestibility at the end of ileum and amino acid composition of ileal digesta. Br. J. Nutr. 55:571-592.

Guilloteau, P., R. Toullec, D. Sauvant, and J. L. Paruelle. 1979. Utilisation des protéines par le veau préruminant à l'engrais. VII - Influence du remplacement des protéines du lait par celles du soja ou de la féverole sur l'évacuation gastrique. Ann. Zootech. 28:1-17. (In French)

Guilloteau, P., and R. Zabielski. 2005. Digestive secretions in preruminant and ruminant calves and some aspects of their regulation. Pages 159-189 in Calf and Heifer Rearing. P. C. Garnsworthy, ed. Nottingham University Press, Nottingham, UK.

Guilloteau, P., R. Zabielski, J. C. David, J. W. Blum, J. A. Morisset, M. Biernat, J. Wolinski, D. Laubitz, V. Romé, and Y. Hamon. 2009. Sodium-butyrate as a growth promoter in milk replacer formula for young mammals. J. Dairy Sci. 92:1038-1049.

Harada, E. 1985. Comparison of pancreatic digestive enzyme secretion induced by volatile fatty acids in mice, Japanese field voles and goats. Comp. Biochem. Physiol. A 81:539-543.

Harada, E., and S. Kato. 1983. Effect of short-chain fatty acids on the secretory response of the ovine exocrine pancreas. Am. J. Physiol. 244:G284-G290.

Katoh, K., and T. Tsuda. 1987. Effects of intravenous injection of butyrate in the exocrine pancreatic secretion in guinea pigs. Comp. Biochem. Physiol. A Physiol. 87:569-572.

Konturek, S. J., R. Zabielski, J. W. Konturek, and J. Czarnecki. 2003 Neuroendocrinology of the pancreas: Role of brain-gut axis in pancreatic secretion. Eur. J. Pharmacol. 481:1-14.

Le Dréan, G., I. Le Huërou-Luron, J. A. Chayvialle, V. Philouze-Romé, M. Gestin, C. Bernard, R. Toullec, and P. Guilloteau. 1997. Kinetics of pancreatic exocrine secretion and plasma gut regulatory peptide release in response to feeding in preruminant and ruminant calves. Comp. Biochem. Physiol. A Physiol. 117:245-255.

Le Dréan, G., I. Le Huërou-Luron, M. Gestin, V. Romé, M. Plodari, C. Bernard, J. A. Chayvialle, and P. Guilloteau. 1998. Comparison of the kinetics of pancreatic secretion and gut regulatory peptides in the plasma of preruminant calf fed milk or soybean protein. J. Dairy Sci. 81:1313-1321.

Le Gall, M., M. Gallois, B. Sève, I. Louveau, J. J. Holst, I. P. Oswald, J. P. Lallès, and P. Guilloteau. 2009. Comparative effects of orally administered sodium butyrate before and after weaning on growth and several indices of gastrointestinal biology of piglets. Br. J. Nutr. 1:1-12

Lowry, O. H., N. J. Rosebrough, A. L. Farr, and R. J. Randall. 1951. Protein measurement with the Folin phenol reagent. J. Biol. Chem. 193:265-275.

Manzanilla, E. G., M. Nofrarias, M. Anguita, M. Castillo, J. F. Perez, S. M. Martin-Orue, C. Kamel, and J. Gasa. 2006. Effects of butyrate, avilamycin, and a plant extract combination on the intestinal equilibrium of early-weaned pigs. J. Anim. Sci. 84:2743-2751.

Mroz, Z. 2005. Organic acids as potential alternative to antibiotic growth promoters for pigs. Adv. Pork Prod. 16:169-182.

Ohbo, M., K. Katoh, and Y. Sasaki. 1996. Effects of saturated fatty acids on amylase release from exocrine pancreatic segments of sheep, rats, hamsters, field voles and mice. J. Comp. Physiol. B 166:305-309.

Pouillart, P. R. 1998. Role of butyric acid and its derivatives in the treatment of colorectal cancer and hemoglobinopathies. Life Sci 63:1739-1760.

Sileikiene, V., R. Mosenthin, M. Tafaj, D. Kruszewka, B. Westöm, I. Mattsson, and S. Pierzinowski. 2005. Effect of short chain fatty acids infused intraileally on interdigestive exocrine pancreatic secretions in growing pigs. J. Anim. Physiol. Anim. Nutr. (Berl.) $89: 253-259$

Toullec, R., and J. P. Lallès. 1995. Digestion dans la caillette et l'intestin grêle. Pages 527-582 in Nutrition des Ruminants Domestiques. R. Jarrige, Y. Ruckebusch, C. Demarquilly, M. H. Farce, and M. Journet, ed. INRA, Paris, France. (In French)

Zabielski, R. C. Dardillat, I. Le Huerou-Luron, C. Bernard, J. A Chayvialle, and P. Guilloteau. 1998a. Periodic fluctuations of gut regulatory peptides in phase with the duodenal migrating myoelectric complex in preruminant calves: Effect of different sources of dietary protein. Br. J. Nutr. 79:287-296.

Zabielski, R., V. Leśniewska, J. Borlak, P. C. Gregory, P. Kiela, S. G. Pierzynowski, and W. Barej. 1998b. Effects of intraduodenal administration of tarazepide on pancreatic secretion and duodenal EMG in neonatal calves. Regul. Pept. 78:113-123. 